\title{
ANALYZING SIMONE DE BEAUVOIR EXISTENTIALIST FEMINISM PERSPECTIVE AND ITS RELEVANCE TOWARDS INDONESIAN WOMEN'S EXISTENCE IN THE PUBLIC SPHERE OF $21^{\text {st }}$ CENTURY
}

\author{
Yulia Rohmawati ${ }^{1}$, Moses Glorino Rumambo Pandin ${ }^{2}$ \\ Faculty of Humanities, Universitas Airlangga
}

\begin{abstract}
The issue of being pro-gender is still a controversial topic to be debated in Indonesian society. However, in the 21 st Century, many women have been able to break through barriers and participate in the public sphere. It is a form of selfexistence as proposed by Simone de Beauvoir on existentialist feminism. Based on these problems, this study aims to find out and answer questions about how Indonesian women exist in the public sphere in the 21 st Century and find out how Indonesian women exist in the public sphere through Simone de Beauvoir's existentialist feminism paradigm. The research method used is descriptivequalitative through a literature review of 23 journal articles, websites, and data reports with a range of 2019-2021. This study found that based on Simone de Beauvoir's feminist paradigm, Indonesian women in the 21 st Century are no longer a figure other than complete. Furthermore, the data collected by the researcher shows that several gender indicators have shown that Indonesian women have been able to occupy public spaces in various aspects. Based on these results, it is hoped that it can provide information about Simone de Beauvoir's existentialist feminism thought and its relevance to the existence of Indonesian women in the public sphere in the 21st Century. However, this research has limitations, those are only about women in Indonesia, and the paradigm of feminism is limited to Simone de Beauvoir's existentialist feminism.
\end{abstract}

Keywords: feminism, gender, public sphere, the existence of Indonesian women, Simone de Beauvoir 


\section{INTRODUCTION}

Gender issues concerning women and their position in Indonesian culture are still interesting topic to be debated in Indonesia. It happens because the patriarchal culture is still rooted in the social system of society. The patriarchal culture positioning women as a figure called "the other" by Simone de Beauvoir. In patriarchal culture, the image of women is described as a figure who must act with full manners, obey, not argue, and must not exceed men over anything (1). Furthermore, a social system with a patriarchal culture assumes that men are stronger than women, both personally in a community and environment (2). Therefore, a feeling of superiority arises from men over women, resulting in an unequal division of roles, where men play a role in the public sphere. In contrast, women are limited to domestic roles.

Even though they are in the confines of a patriarchal culture, the existence of women is increasingly visible along with the times. This is recorded in the movement of history, as mentioned by Kuntowijoyo that history has considered women as individuals who can stand alone (3). Furthermore, when viewed from a historical perspective, there have been many movements of Indonesian women in the public sphere. In the 20th Century, women's organizations were born that boldly penetrated the public sphere, including the Indonesian Women's Union (Perwari) and the Indonesian Women's Congress (Kowani). Meanwhile, in the New Order era, there was the Indonesian Women's Movement (Gerwani) and the Dharma Wanita (4).

The women's movements that have rooted since the 20th Century are a significant start for Indonesian women's existence. However, this cannot fully open up space and opportunities for women to show their work in public spaces. Based on data from BPS, the percentage of the female population in Indonesia is $49.2 \%$. Meanwhile, the percentage of the male population is $50.58 \%$ (5). From this percentage, it can be seen that the number of men and women in Indonesia is almost equal. However, many female residents, which is almost equal to the male population, do not necessarily realize gender equality between the two parties. In 
other words, there is still a gender gap between men and women, where men have more freedom in the public sphere while women only dwell on domestic roles.

Table 1. Gender Inequality Index and its Compiling Components, 2015-2019

\begin{tabular}{|c|c|c|c|c|c|c|c|c|c|}
\hline \multirow[t]{2}{*}{ Year } & \multirow{2}{*}{$\begin{array}{c}\text { The } \\
\text { proportio } \\
\mathrm{n} \text { of } \\
\text { deliveries } \\
\text { with no } \\
\text { health } \\
\text { facilities } \\
(\%)\end{array}$} & \multirow{2}{*}{$\begin{array}{c}\text { The } \\
\text { proportio } \\
\mathrm{n} \text { of } \\
\text { women in } \\
<20 \text { in } \\
\text { giving } \\
\text { first baby } \\
\text { birth (\%) }\end{array}$} & \multicolumn{2}{|c|}{$\begin{array}{l}\text { Percentage of } \\
\text { women in } \\
\text { parliament (\%) }\end{array}$} & \multicolumn{2}{|c|}{$\begin{array}{c}\text { The proportion } \\
\text { of citizens } 25+ \\
\text { with minimum } \\
\text { education in } \\
\text { high school } \\
\text { (\%) }\end{array}$} & \multicolumn{2}{|c|}{$\begin{array}{l}\text { Participation of } \\
\text { workforce based } \\
\text { on gender (\%) }\end{array}$} & \multirow{2}{*}{$\begin{array}{c}\text { Gender } \\
\text { Inequa } \\
\text { ity } \\
\text { Index }\end{array}$} \\
\hline & & & Men & Women & Men & Women & Men & Women & \\
\hline 2015 & 22,4 & 27,0 & 82,7 & 17,3 & 37,8 & 31,7 & 82,7 & 48,9 & 0,466 \\
\hline 2016 & 20,3 & 26,2 & 82,7 & 17,3 & 38,9 & 31,9 & 82,0 & 50,8 & 0,454 \\
\hline 2017 & 18,7 & 25,3 & 82,7 & 17,3 & 38,1 & 31,6 & 82,5 & 50,9 & 0,445 \\
\hline 2018 & 17,3 & 24,1 & 82,7 & 17,3 & 38,3 & 31,0 & 82,7 & 51,9 & 0,436 \\
\hline 2019 & 14,1 & 27,1 & 79,5 & 20,5 & 39,8 & 31,9 & 83,1 & 51,9 & 0,421 \\
\hline
\end{tabular}

Source: Gender Inequality Index 2020

Inequality in roles between men and women in the public sphere covers various aspects, such as education, labor force participation, and the fulfillment of strategic job positions. Based on research from Mckinsey in 2018, the number of male and female graduates in higher education is almost equal. However, in the world of work, only about $20 \%$ of female graduates work in positions in middle management. The higher the status or title, the less the percentage. The remaining $5 \%$ of women occupy high positions or positions such as Chief Executive Officer (CEO) (6).

As a form of resistance to inequality, in the 21 st Century, there have been many movements of women activists with a feminist premise to fight for women's 
rights and gender equality. Feminism is a form of social change and resistance to obtain equal status and equal rights between men and women. The feminist movement exists to break down the social system in which men hold full power and dominate the spaces that should be occupied by women (7). Feminism assumes that women were oppressed and exploited. Therefore, feminism initially focused on the politics of sexuality and women's domestication, from the personal to the general level. Simone de Beauvoir pioneered the feminist movement that has mushroomed to this day in her thoughts on existentialist feminism (8).

Women in gender construction often experience marginalization and subordination. Beauvoir argues that one form of subordination of women is to make men more accessible. Women's resistance to the marginalization of women can be solved by rejecting women for figures inherent in women. By leaving the other, it means refusing to be constructed as an object. Thus, women can be free from all forms of marginalization that make them "the other" person (9).

Regarding the existence of women in the public sphere, Beauvoir views that the public sphere should be a friendly space for women. The presence of a prohibition for women to exist in public spaces is a form of restraint against efforts to find women's identity. The opening of opportunities for women to take part in public sphere can suggest breaking the chain of women's independence caused by their social environment (10).

Nowadays, Indonesian women have had enough opportunities to take part in the public sphere. However, few Indonesian women hold strategic positions, for example, in political leadership and other public spheres. The realization of the openness of public space for women requires a relatively complex and gradual process. Therefore, this study was conducted to determine how the existence of Indonesian women in public spaces in 21 st century the as well as knowing how Indonesian women exist in the public sphere through the viewpoint of feminist existentialist Simone de Beauvoir. 


\section{METHOD}

The method used in this study is a qualitative-descriptive research method through literature review. Qualitative methods are used in research to show social phenomena in society, ranging from history, behavior, organizational functionalism to kinship (11). Meanwhile, descriptive analysis is used to describe the problems and research results based on Simone de Beauvoir's approach to the concept of feminism.

The object of this research is the existence of Indonesian women in the public sphere, as illustrated in Simone de Beauvoir's feminist thought. The data is taken through a literature review on journal articles and statistical information relevant to the problems raised in the study. Moreover, the data is processed by reading, sorting, and analyzing according to the feminism concept of Simone de Beauvoir. Then, the conclusions are made from the results of the analysis and processing of the data.

Data collection techniques are carried out through literature studies in journals and data reports that have specific criteria. The criteria are as follows: 1) journal articles with keywords in the form of "the existence of Indonesian women", "feminism," "public sphere," "Simone de Beauvoir"; 2) journal articles published between 2019 to 2021 ; 3) articles published at validated journals, such as the journal Metasastra, Al-wardah: Journal of Women, Gender and Religion Studies, Journal of Communication Studies and Media Studies, compiled through google scholars and research gate; 4) data is a report taken from the website and the institution relevant to the research. The data report compiled by the author is based on Gender Inequality Index 2020 shown by BPS and the Ministry of Women's Empowerment and Child Protection Gender-Based Human Development Study 2020.

The data analysis was carried out using inductive techniques analysis. Data analysis technique using the inductive technique is data analysis that departs from specific factors in nature to draw general conclusions. This analytical technique tends to be used more in qualitative research methods. As stated in the book Qualitative Research Methods in the Field of Language Education, page 296, in this inductive technique, the research does not aim to prove the truth of a hypothesis. 
The analysis is carried out based on information obtained in the field. To arrive at the findings, conclusions can be drawn in the form of a theory based on patterns in the real world (11)

Based on the book entitled Qualitative Methodology written by Dr. Mamik, on page 170 it is stated that it consists of at least three stages in the analysis after the data collection process (12). The stages are as follows:

1. Data reduction

Data reduction is a process of selection, simplification, and abstraction of the data that has been collected. The data reduction is performed by the coherence process. Based on a book entitled Basic Research Methodology written by Dr. Sandu Siyoto and M. Ali Sodik, in pages 122-123, stated that data reduction could be made through abstraction, by making a summary of the core, processes, and statements that need to be maintained so that they remain in the research data. In other words, data abstraction is carried out to produce core records from the data obtained from the results of data mining. The data obtained in research are often complicated and sometimes not following the research theme. To avoid mixing necessary and unnecessary data, data reduction was carried out to simplify the data and remove irrelevant data to ensure that the data obtained are under the research scope (13).

2. Presentation of data

Data that has been reduced and selected can be presented coherently, resulting in structured information ready for conclusions to be drawn. The data analysis results in this study were carried out in a descriptive narrative accompanied by a table. Referring to the book Basic Research Methodology written by Dr. Sandu Siyoto and M. Ali Sodik on page 123, the presentation of the data is done because research data with qualitative methods are more dominant in narrative form, thus requiring simplification without reducing content (13).

3. Conclusion drawing and data verification

After going through the above stages, the research data is ready to be drawn conclusions and verified by looking at and questioning again to 
obtain a more precise understanding. The verification process for temporary findings can be carried out by repeating the research steps, namely by tracing back all the research steps carried out. In detail, in the book entitled Metode Penelitian Kualitatif dalam Bidang Pendidikan Bahasa, page 177, it is stated that concluding includes concluded examining the collected data, reductions made based on research notes, and tentative conclusions that have been formulated (11)

\section{RESULTS}

In line with the criteria, it can be detailed that the results obtained through the literature review is the journal published in 20211 journal article (4.54\%), 213 journal articles published in 2020(59.9\%), in 2019 as many as 8 journals (36.6\%), and one book, which discusses qualitative data in the field of education that was published in 2019. In addition, some data are taken from the kata.data.co.id website, study reports from BPS and the Kemenpppa, which are relevant to the research problems.

Overall, the results of data analysis from the literature review indicates that Indonesian women in the public sphere in the 21 st Century have shown relevance to Simone de Beauvoir's feminist thought. Nevertheless, upon closer inspection, the results of the data analysis cover various aspects. Therefore, the authors describe the results of data analysis in four elements as follows.

1. The existence of Indonesian women in the public sphere based on the historical paradigm

Based on data obtained from a research journal article by Ririn Darini entitled Gait of Majapahit Women in the Political Room, the data obtained are that: During the Hindu-Buddhist kingdom in Indonesia, there were already female leaders, such as Ratu Shima, who led the Kalingga Kingdom (Central Java), Pramodhawardhani from the Ancient Mataram Kingdom, the Syailendra dynasty, Queen Mother Rajapatni and Ratu Tribhuwana Tunggadewi who held a strong influence on each of them. 
Furthermore, the existence of women in Indonesia was increasingly visible in the 19th and 20th centuries. There are several journal articles that the authors refer to in obtaining the data. The first is a research journal article by Ari Hermawan, et al., entitled Gender Equality in the XIX Century in Indonesia in the work of RA Kartini. Data obtained by the researchers in the journal article is that study of gender equality in Indonesia in the 19th Century can be seen from the historical paradigm. The study analyzes the works of RA Kartini as a representation of women's struggle in his time.

This data is also accompanied by other research articles, such as that written by Budi Sujati, Ilfa Harfiatul Haq on the Women's Movement in Java (1912-1941). In that article, the existence of Indonesian women in history can be seen from educational movements, organizations, congresses, and the struggle for rights. Second, the results of Silvy Mei Pradita's research entitled The History of the 19-20 Century Indonesian Women's Movement: A Historical Review of the Role of Women in National Education shows that In the 20th Century, women's organizations that were active in the public sphere were born, such as the Indonesian Women's Union (Perwari) and the Indonesian Women's Congress (Kowani), the Indonesian Women's Movement (Gerwani), and Dharma Wanita during the Orde Baru (new order era).

However, in Muslim Pohan's research article on Sexual Politics of Post-Independence Women's Organizations in Indonesia, the other data found that women's organizations or women's movements in postindependence Indonesia experienced a lot of sexual-based politicization, such as GERWANI. Thus, the author tries to find a comparison of women's political movements through data analysis in a journal article entitled Pattern and Orientation of Indonesian Women's Movement: Comparison of Women's Movement in the Era Before and After the Reform, which provides a comparison of women's organizations in before and after the Reformation.

The results of data analysis on sources referred to by the author show that the existence of Indonesian women in the public sphere can be traced from the course of national history. From the classical period to post- 
independence, the role of women can not be underestimated and is seen as a figure of otherness, as mentioned by Simone de Beauvoir.

2. The existence of Indonesian women in the public sphere in terms of social and political aspects

Politics is an essential aspect in measuring the existence of women in the public sphere. Amin Bendar, in his research on Feminism and Social Movements shows the subordinate position of women and explains the world's economic and political system does not privilege the role of women. In the world of Indonesian politics, the phenomenon of patriarchal culture affects women's political participation. This phenomenon can be seen from the low participation of women in the legislature, especially in Gianyar, Bali. The data results from an analysis based on the research journal Women and Cultural Patriarchy in Politics.

To equalize the positions of men and women, in the political space, especially in the legislative seats, women get a representation quota of $30 \%$. In the first research journal article on the Role of Women in Politics in the Era of Democracy, Hendrarto explained that to achieve a $30 \%$ percent of women's representation in legislative seats, Law no. 8 of 2012 concerning Legislative Elections. A research journal article from Hamidah Abdurrachman, et al., entitled Women's Quotas in the Central Java DPRD in the 2014 and 2019 Elections, describes that women's representation in parliament can be presented using geographical representation, ideological division in society through political parties, independent representatives, or the combination of those political parties and independent representatives.

As for other supporting data, the authors have collected from several websites, such as the BPS website, to obtain data on the percentage of women and men in Indonesia to compare the two sexes. Then, the website katadata.co.id provides supporting data regarding the percentage of women who become high leaders in a company. Then, the last one is the website Kemenpppa which contains a gender-based human development report in 2020. That is one of the indicators that show a picture of the existence of Indonesian women in the public sphere in this modern era. 
3. Simone de beauvoir's existentialist feminism in literary studies

Literature field is an area that is closed to feminism studies. Therefore, the author collects some data from research journal articles that discuss feminist thought in literary works. First is a research article from Karkono, et al. that discusses Patriarchal Culture in the Kartini Film (2017) Hanung Bramantyo. The data obtained are in the form of a collection of descriptions of patriarchal culture, the resistance of Kartini's figures to patriarchal culture, and other characters' reactions to Kartini's opposition in the Kartini film.

The data is also supported by a research article from Resti Nurfaidah with the title Membaca Perempuan dalam “Celoteh Perempuan”. Celoteh Perempuan is a collection of short stories in which there is a study of feminism and women, although not explicitly. The analysis results obtained in the article are that the female characters in Talking Women are (a) women who can exist, and (b) the decisions taken by female figures have not been accepted from the perspective of the social realm.

Beauvoir's analysis of existentialist feminism can also be seen in Kristanti Purnami and Dedi Pramono's research on the Existence of Women in Seno Gumira Ajidarma's Book of Omong Kosong Novel: A Study of Existentialist Feminism by Simone De Beauvoir. It was explained that there is an effort to marginalize women in the novel. Kitab Omong Blank by Seno Gumira Ajidarma is the position of women who are always seen as weak and have no authority.

Then, there is a research article by Rindi Setyia Rahayu on the analysis of literary works based on Simone de Beauvoir's study of existentialist feminism, namely the journal entitled The Existence of Women in a Collection of Short Stories of Pemilin Death by Dwi Ratih Ramadhany: A Study of Feminism by Simone De Beauvoir. The data collected in the research article is that the existence of women in the collection of short stories consists of existence through nature, through history, and presence through myth. Meanwhile, women's efforts to achieve their existence in a group of short stories consist of accepting themselves as other figures and 
rejecting themselves as other figures by becoming intelligent women and having a free career.

4. The existence of women in Simone de Beauvoir's existentialist feminism

In this study, there are sources of research journal articles that discuss Simone de Beauvoir's feminism from various perspectives. The first research article that became a reference for data collection by the author was Ni Putu Laksmi Mutiara Prameswari1, Wahyu Budi Nugroho, Ni Made Anggita Sastri Mahadewi. The article's title is Simone De Beauvoir's Existential Feminism: Women's Struggle in the Domestic Area. The result of data analysis in the reference source is that the concept of Beauvoir's feminism is famous for the term woman as the other figure. There is a feminine mystery where women accept otherness as a tragic act passed down from generation to generation. The struggle for women in the domestic sphere, according to existential feminism, is to become "free women."

Beauvoir's feminist thought is heavily influenced by the existentialist philosophical thought of Jean Paul Sartre. Joy Moses E Simbolon, in his research article entitled God's Existentialism: An Analysis of the Views and Criticisms of Jean-Paul Sartre, stated that Sartre said that the real freedom is that humans are willing to deny the existence of God in every aspect of their lives. Both Sartre and Beauvoir believe that every human being must have self-existence, be free to choose, and independently determine his own life.

There is an additional data on feminism from another perspective, for instance, the research article feminism in the postmodernism period by Ni Putu Sri Pratiwi et al. The article stated that the essence of feminism is to realize equal rights and dignity and the freedom to control body and life, both in the domestic and public spheres.

Based on the analysis results, key components were obtained that could answer the questions in this study. The author discusses the answers to these questions in the next section. The answers to these questions in more detail in the discussion section. 


\section{DISCUSSION}

\section{The Existence of Indonesian Women in the Historical Movement}

Long before the 21st Century, the existence of women in Indonesia has begun to be seen and recognized in the historical movement. When establishing the Hindu-Buddhist kingdoms in Indonesia and Java. In particular, the role of women in the public sphere was seen and gained legitimacy from the domain. For example, a female character named Ratu Shima was the leader of the Kalingga Kingdom (Central Java) in the seventh Century, who was known for her firmness and flexibility in leading. In addition, there is also the figure of Pramodhawardhani from the Ancient Mataram Kingdom, the Syailendra dynasty in the IX century, who ruled the Medang kingdom to replace his father. Then, during the Majapahit Kingdom, a queen mother Rajapatni, had a significant influence in the kingdom and did not forget Queen Tribhuanatunggadewi, who reigned in the XIV (14th) century.

Around the 19th Century, the existence of women in Indonesia began to be influenced by the feminist movement that mushroomed in the west. The women's movement in Indonesia was initially focused on the struggle against colonialism and obtaining a more decent social position. Considering that women were often looked as objects, forced to have earlier marriage, and polygamy, several female figures demonstrated this movement in several regions in Indonesia, such as RA Kartini in Jepara, Dewi Sartika in Bandung, to Tjut Nyak Dien in Aceh. The rights fought for by women in Indonesia are the share of women around the world. This is due to the feminist women's group in London who prefer to use rather a gender discourse issues than issues patriarchal. Gender issues in Indonesia are better known as "women's emancipation" with the icon of RA Kartini (15).

The existence of Indonesian women in the public sphere was increasingly visible in the following centuries. This is evidenced by the growing development of women's organizations divided into several periods, namely the period before the proclamation of Indonesian independence, the period after the declaration of independence (1945-1965), and the period after 1965 Orde Baru. However, the development of women's organizations as a form of existence often experiences ups and downs. In the pre-independence period, women's organizations were more 
accessible, so they could participate in repelling colonialism and maintaining independence. Furthermore, in the period of freedom (1945-1965), women's organizations improved the fate of women and raised the status of women (16). On the other hand, during the Soeharto era (the new order), women's organizations began to decline. Women's organizations began to be controlled by the government. As a result, the movements and voices are increasingly limited and only given freedom for domestic activities, such as the organization of the wives of servants of the state and women's dharma (17).

Since the reform era, the women's movement began to rise again. The role of women in the public sphere is increasingly recognized. It is proven by the increasing number of women who become regional leaders, political party cadres, professional staff, and other strategic and profitable positions for women. In addition, in subsequent periods, the women's movement received more and more support. There are various women's empowerment activities under independent and dependent NGOs that support women to exist.

\section{The Existence of Indonesian Women in the Public Space in the 21st Century}

If we refer to the historical side, it can be seen that the struggle of Indonesian women in showing their identity and existence has been seen for a long time, even long before this 21 st Century. Indonesian women, which is increasingly visible from time to time, also give rise to a discourse on gender equality. Until now, issues of gender equality are increasingly emerging amid the increasingly strong current of the feminist movement.

The demands of feminism present in various lines of life motivate women to become equal partners with men. Therefore, the space for women's existence is increasingly wide open, for example, in science and technology, which is increasingly friendly to women's potential, as evidenced by awards for female scientists. In addition, women in the 21 st Century are also expanding in the economic, educational, health, and political aspects (18).

Based on the results of the literature study and analysis of the data obtained, it can be concluded that there is relevance between Simone de Beauvoir's feminist 
thought and the existence of Indonesian women in the public sphere, especially in the 21 st Century. In general, the description of the existence of Indonesian women in the public sphere can be shown in several indicators, for example, the involvement of women in parliament, work as professionals or academicians, and based on the level of contribution of women's income. The following table shows the status of women's existence based on the indicators mentioned in the 2017-2018 period.

Graphic 1. Components of the Gender Empowerment Index (IDG), 2016-2019
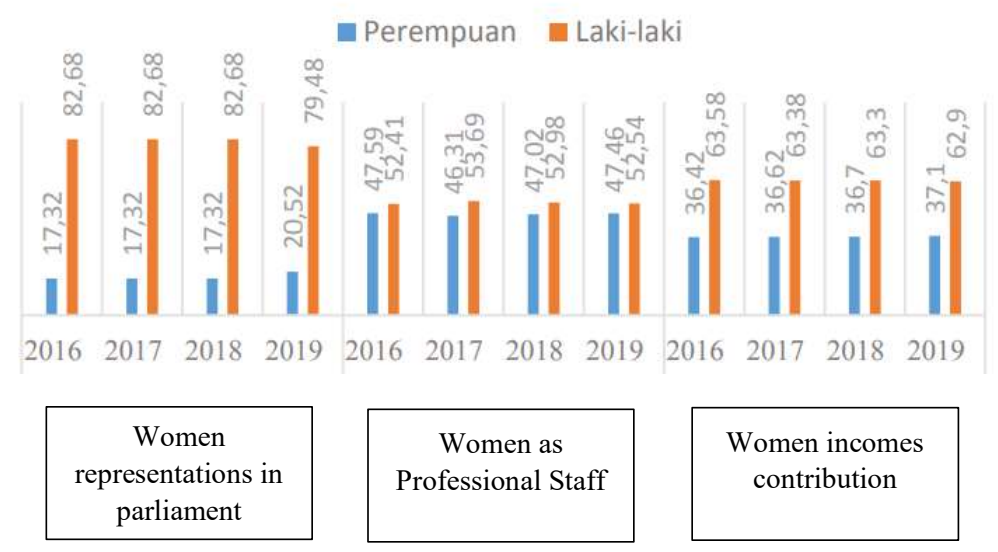

Source: Gender-Based Human Development Study 2020

Along with the increasing awareness of gender equality, many discourses encourage the realization of increased representation of women in parliament. However, the representation of women in parliament is limited to a minimum quota of $30 \%$. The representation of women in parliament can be presented in at least several forms: (1) geographical representation, which implies that each region has members of the legislature who are elected and accountable to their respective regions; (2) ideological divisions in society that can be represented in the legislature through political parties, independent representatives, and or a combination of both; (3) the legislature represents the political situation of the existing parties in a country even if the political parties do not have an ideological basis (19).

In order to achieve this goal, the law number 8, 2012, concerning legislative elections which instructs political parties to include at least $30 \%$ of women in the list of candidates for legislative members (20). The provision of a minimum quota 
of $30 \%$ has been able to increase the existence of women in parliament, even though the fulfilled percentage is still below the minimum limit. This can be seen in the following table, where there is an increase from period to period. Thus, for example, in 1999 there was a decrease, but there was a significant increase again after that.

Table 3. The Representation of IndIndonesian Women in Parliament

\begin{tabular}{|c|c|c|c|c|}
\hline No & Election year & Men & Women & $\begin{array}{l}\text { The percentage of } \\
\text { women based on } \\
\text { election results }\end{array}$ \\
\hline 1 & 1955 & 256 & 16 & 5,88 \\
\hline 2 & 1971 & 429 & 31 & 6,74 \\
\hline 3 & 1977 & 423 & 37 & 8,04 \\
\hline 4 & 1982 & 418 & 42 & 9,13 \\
\hline 5 & 1987 & 441 & 59 & 118 \\
\hline 6 & 1992 & 438 & 62 & 12,4 \\
\hline 7 & 1997 & 442 & 58 & 11,6 \\
\hline 8 & 1999 & 456 & 44 & 8,8 \\
\hline 9 & 2004 & 485 & 65 & 11,82 \\
\hline 10 & 2009 & 460 & 100 & 17,86 \\
\hline 11 & 2014 & 463 & 97 & 17,32 \\
\hline 12 & 2019 & 455 & 120 & 20,87 \\
\hline
\end{tabular}

Source: Gender-Based Human Development Study 2019

In addition, based on data compiled by BPS regarding women's career positions as managers, the results show that there is an increase in the percentage. It indicates that the existence of women in the public sphere in the 21 st Century is starting to show a positive trend and brings good prospects in the future.

Table 4. The Distribution of Manager Position based on Gender 2016-2019 


\begin{tabular}{|c|c|c|c|c|}
\hline \multirow{2}{*}{$\begin{array}{c}\text { Gender } \\
\text { identity }\end{array}$} & \multicolumn{4}{|c|}{ The distribution of manager position based on gender identity } \\
\cline { 2 - 5 } & $\mathbf{2 0 1 6}$ & $\mathbf{2 0 1 7}$ & $\mathbf{2 0 1 8}$ & $\mathbf{2 0 1 9}$ \\
\hline Men & $75,83 \%$ & $73,37 \%$ & $71,03 \%$ & $69,37 \%$ \\
\hline Women & $24,17 \%$ & $26,63 \%$ & $28,97 \%$ & $30,63 \%$ \\
\hline
\end{tabular}

Source: Central Bureau of Statistics

Based on some data and the indicators described above, it can be seen that Indonesian women have been able to exist in the public sphere in the modern era, precisely in the 21 st Century. Some of the indicators above are essential aspects in measuring the extent of the existence of Indonesian women in the public sphere. Although not completely perfect, the various percentages and increases shown in the data above represent excellent prospects for advancing gender equality and women's freedom to exist in the public sphere.

\section{The Existence of Indonesian Women in Public Space in the 21st Century in the Perspective of Feminism Simone de Beauvoir}

Simone de Beauvoir is a female philosopher from France who lived in the 20th Century. He was born in 1908 to a bourgeois and traditional family. As a child, she was educated in an all-girls school to influence her thoughts and broad insights about women. Little Beauvoir is also a devout and obedient figure to religion and family. However, when he was a teenager, he experienced a crisis of belief, resulting in him becoming an atheist.

Beauvoir's feminist thought cannot be separated from the educational role of his parents, who are bourgeois groups. Beauvoir is a figure who holds fast to the Catholic religion and provides moral education to Beauvoir, who tends to be conservative. Meanwhile, his father is an idealist and rationalist, which is contrary to the character of his mother's education. This is a paradox and is believed to be a factor that made Beauvoir a crisis of confidence.

At the age of 21, Beauvoir met Jean Paul Sartre, who was also famous for his existentialist philosophy. The two of them had a special relationship until the end of their lives. Because of this relationship, Beauvoir's thinking was heavily 
influenced by Sartre's existentialist thought. According to Sartre, humans exist because of human awareness of themselves. Therefore, man is not a thing or object. The existence of an object simultaneously explains the essence of the object, but the presence of humans cannot explain the importance of humans. Thus, according to Sartre, existence precedes essence (21). The Beauvoir's thoughts on existentialist feminism are then outlined in the book entitled The Second Sex. The Second Sex by Simone de Beauvoir's became one of the fundamental references for the feminist movement in the 1970s. In building conception, women tried to free themselves from the exploitation and oppression they experienced. The essence of feminism is to realize equal rights and dignity and freedom to control body and life, both in the domestic and public spheres (22).

Beauvoir existentialist feminism views the existence of women based on nature, history, and myth. To achieve validation, women should accept themselves as another person or reject themselves as another person to take advantage of women's acceptance, which means getting themselves to achieve freedom. The second is women's efforts to achieve existence by rejecting themselves as other figures. The point is women's efforts to emancipate, fight, be active, able to take responsibility for something and reject the passivity that men usually emphasize to achieve freedom (23).

In line with existentialist feminism, Beauvoir argues that a woman must show herself or exist as a human being. Beauvoir said that the body is not an object or object but a situation and grip on the world and a human sketch of the social world. The body and all attributes have social characteristics related to the space in which they live and work. Meanwhile, in the social aspect, the body becomes the central element of personal identity (24).

Nowadays, the reality of women in Indonesia is that many women can fight for their desires and dreams independently. Women have the freedom to determine the direction and choices of their lives without restrictions and prohibitions from anywhere, both in the domestic and public spheres. This is what de Beauvoir means about existentialist feminism. This conception requires self-esteem (to be a person) and freedom from servitude (to be able to choose) for women by acknowledging all 
their potential as subjects, not just objects, as in Simone de Beauvoir's idea of existentialist feminism (25).

According to the indices mentioned above, it can be seen that in this modernization era, the existence of women has become increasingly visible and cannot be underestimated. Although it is not maximized, some of these indexes show that the prospects for the presence of women in the public sphere in the future are quite promising. It is necessary to strengthen synergies from various lines, from the government, academics, to community leaders, to properly support the existence of Indonesian women in the public sphere. The strategy that can be done is to promote gender equality to actualize the protection of women's rights as whole human beings (26). In addition, the government should meet the challenge of defining gender policies that are consistent and have a positive impact on overall development goals (27).

\section{CONCLUSION}

Gender issues have become a discourse that raises pros and cons that happened at this time and centuries ago. In Indonesia, gender issues have become a serious problem that occurs because patriarchal culture is still rooted in the social system of society. For example, the patriarchal culture positioning women as a figure called the other by Simone de Beauvoir.

In the 21th Century, women's organizations were born to participate in the public sphere. The women's movements that have mushroomed since the 20th Century are a good start for the existence of Indonesian women. Although it is a good start, the opportunity to survive through these movements cannot necessarily open up the freedom for women to take part in the public sphere. It is because there are still various restrictions and prohibitions that marginalize and subordinate women.

As a form of resistance against inequality, in the 21 st Century, there have been many movements of women activists with a feminist premise to fight for women's rights and gender equality. One of the figures who have feminist thoughts is Simone de Beauvoir, which was her existentialist feminism. In existentialist 
feminism, Beauvoir said that women must show themselves or exist as human beings. The body is not an object or object because the body and its aspects also have social characteristics related to space and work life.

Based on the study results, it can be concluded that Indonesian women in the public sphere in the 21 st Century have shown a significant role. Indonesian women can exist independently and free from certain limitations. In the field of parliamentary politics, for example, data compiled by researchers shows that at the beginning of the 1955 general election, the number of female members of parliament only reached 16 . However, in the 21 st Century, the number of female parliamentarians is 120 or $20.5 \%$. It is such a good progress, although not entirely perfect.

In addition, another indicator that shows that Indonesian women have been able to exist in the public sphere is the percentage of women's managerial positions. Based on data collected by researchers, in 2016, the percentage of women as managers was only $24.17 \%$. Meanwhile, in 2019, the percentage of women occupying managerial positions reached $20.36 \%$.

Answering how the existence of Indonesian women in the public sphere in the 21 st Century based on Simone de Beauvoir's existentialist feminism perspective can be reviewed and correlated with data on women's roles in politics, job positions, and gender development index in Indonesia as compiled by researchers. Based on the data that has been presented in the tables in the discussion section, it can be concluded that when viewed through Simone de Beauvoir's existentialist feminism paradigm, Indonesian women have been able to determine their existence and are no longer a figure other than what Beauvoir calls them. This is what de Beauvoir means about existentialist feminism. This conception requires self-esteem (to be a person) and freedom from servitude (to choose) for women by acknowledging all their potential as subjects, not just objects, in Simone de Beauvoir's existentialist feminism. 


\section{REFERENCES}

1. Karkono, Maulida J, Rahmadiyanti PS. Patriarchy Culture in Kartini Film ( 2017 ) By Hanung Bramantyo. 2020;2(April):15-27.

2. Wayan KYI, Nyoman S. Women and Cultural Patriarchy in Politics. 2020;(12):2158-64.

3. Sujati B, Ilfa Harfiatul Haq. Gerakan Perempuan di Jawa (1912-1941). Ishlah J Ilmu Ushuluddin, Adab dan Dakwah. 2020;2(1):16-31.

4. Pradita SM. Sejarah Pergerakan Perempuan Indonesia Abad 19 - 20: Tinjauan Historis Peran Perempuan dalam Pendidikan Bangsa. Chronol J Hist Educ [Internet]. 2020;2(2):12-27. Available at: https://journal.uhamka.ac.id/index.php/jhe/article/view/6060

5. BPS. Sensus Penduduk Indonesia Tahun 2020 [Internet]. 2021 [dikutip 26 April 2021]. Available at: https://www.bps.go.id/pressrelease/2021/01/21/1854/hasil-sensuspenduduk-2020.html

6. Annur CM. Cuma 20\% di Level Tengah, Mengapa Perempuan Penting Pimpin Perusahaan? https://katadata.co.id/pingitaria/digital/5e9a4e55e32 [Internet]. 2019 [Cited 5 Mei 2021]. Available at: https://katadata.co.id/pingitaria/digital/5e9a4e55e32f1/cuma-20-di-leveltengah-mengapa-perempuan-penting-pimpin-perusahaan

7. Bendar A. Feminisme Dan Gerakan Sosial. Al-Wardah. 2020;13(1):25.

8. Nugroho NPLMPWB, Mahadewi NMAS. Feminisme Eksistensial Simone de Beauvoir: Perjuangan Perempuan di Ranah Domestik. Jurnal Ilmiah Sosiologi [Internet]. 2019;1(2):1-13. Available at: https://ojs.unud.ac.id/index.php/sorot/article/view/51955

9. Purnami K, Pramono D. Eksistensi Perempuan Dalam Novel Kitab Omong Kosong Karya Seno Gumira Ajidarma : Kajian Feminisme Eksistensialis Simone De Beauvoir. 2021;2(1):54-62.

10. Nurfaidah R. Membaca Perempuan Dalam Celoteh Perempuan. METASASTRA. 2019;11(2):157.

11. Nugrahani F. Metode Penelitian Kualitatif dalam Bidang Pendidikan Bahasa. Solo: Cakra Books; 2014.

12. Mamik. Metodologi Kualitatif. Sidoarjo: PT Zifatama Publisher; 2015.

13. Siyoto S, Sodik A. Dasar Metodologi Penelitian. Sleman: Literasi Media Publishing; 2015.

14. Darini R. Kiprah Perempuan Majapahit di Ruang Politik. Patrawidya. 2019;20(1):101-13.

15. Hermawan A, Purnomo B, Wahyuni A. Kesetaraan Gender Pada Abad Xix Di Indonesia Dalam Karya Ra Kartini Gender Equality In The Xix Century 
In Indonesia In The Works Of Ra Kartini. II:50-8.

16. Pohan M. Politik Seksual Terhadap Organisasi Perempuan Pasca Kemerdekaan Di Indonesia. Orphanet J Rare Dis. 2020; 21 (1): 1-9.

17. Hapsari YD, Utami T, Wijaya M, Rahmawati T. Pattern and Orientation of Indonesian Women's Movement: Comparison of Women Movement in the Era Before and After the Reform. 2020;510(Icosaps):483-8.

18. Abbas N. Dampak Feminisme Pada Perempuan Nurhasnah Abbas. Alwardah: Jurnal Kajian Perempuan, Gend dan Agama. 2020;14(2):187-98.

19. Abdurrachman H, Riyanti R, Nugraha RA. Kuota Perempuan Di Dprd Jawa Tengah Pada Pemilu 2014 Dan Pemilu 2019. Perspektif Hukum. 2019;19(1):124.

20. Hendrarto. Peran Perempuan dalam Politik di Era Demokrasi. Jurnal Komunikasi DAN Kajian MEDIA [Internet]. 2019;3(1):56-69. Tersedia pada:

https://jurnal.untidar.ac.id/index.php/komunikasi/article/view/1363/907

21. Simbolon JME. Eksistensialisme Tuhan Analisis Terhadap Pandangan Dan Kritik Jean-Paul Sartre. 2020;4(1):93-103.

22. Partiwi, N., Nugroho, W., Mahadewi. N. Feminisme Posmodern Luce Irigaray: Pembebasan Perempuan dari Bahasa Patriarki. Jurnal Ilmiah Sosiologi. [Internet]. 2020;1(1). Available at: https://ojs.unud.ac.id/index.php/sorot/article/view/59516/34586

23. Rahayu RS. Eksistensi Perempuan dalam Kumpulan Cerita Pendek Pemilin Kematian Karya Dwi Ratih Ramadhany: Kajian Feminisme Simone De Beauvoir. Sapala. 2019;1(1):1-11.

24. Purwanti T. Kuasa Tubuh dan Perlawanan: Anti Politisasi dan Komodifikasi Tubuh Perempuan dalam Ruang Virtual. Umbara. 2020;5(2):141.

25. Shalihin N, Firdaus F. Transformasi Gender: Strategi Pembebasan Perempuan dari Jerat Pembangunan dan Kapitalisme. Sawwa Jurnal Studi Gender. 2019;14(1):109.

26. Sugiarti Y, Sutrisni S. emberdayaan Perempuan Melalui Wirausaha Pengolahan Buah Siwalan Di Desa Banuaju Timur Kecamatan BatangBatang. J ABDIRAJA. 2020;3(2):15-7.

27. Chotim EE. Kesetaraan Gender Dan Pemberdayaan Perempuan Di Indonesia : Keinginan Dan Keniscayaan Pendekatan Pragmatis (Studi Terhadap Ukm Cirebon Home Made). AKSELERASI. 2020;2(1):70-82. 